\title{
Sobre as inclinaçôes carnais: inflexões do pensamento cristão sobre os desejos e as sensaçôes prazerosas do baixo corporal ${ }^{1}$
}

\section{| ${ }^{1}$ Luís Felipe Rios, ${ }^{2}$ Richard Parker, ${ }^{3}$ Veriano Terto Junior |}

Resumo: Este ensaio consiste numa revisão sobre os significados da "carne" no Ocidente, enfocando seu trato no âmbito do cristianismo. Nossa expectativa é a de que um trabalho desta ordem possa auxiliar a iluminar as compreensões atuais sobre as questôes referentes à sexualidade dentro e fora dos contextos religiosos do Brasil contemporâneo. Questôes, lembramos, de especial interesse para os preocupados com velhas e novas problemáticas localizadas no campo do que se tem denominado direitos sexuais e reprodutivos, com repercussões no campo da Saúde Pública.

> Palavras-chave: Sexualidade, cristianismo, religião.
1 Doutor em Saúde Coletiva. Professor do Programa de Pósgraduação em Antropologia da Universidade Federal de Pernambuco. Coordenador do Laboratório de Estudos da Sexualidade Humana (LabESHU). Endereço eletrônico: fipo@bol.com.br

${ }^{2}$ Doutor em Antropologia. Professor do Departamento de Ciências Sociomédicas e Diretor do Centro de Gênero, Sexualidade e Saúde da Escola Mailman de Saúde Pública da Universidade de Colúmbia. Endereço eletrônico: rgp11@ columbia.edu.

${ }^{3}$ Doutor em Saúde Coletiva. Coordenador da Associação Brasileira Interdisciplinar de Aids. Endereço eletrônico: verterto@abiaids.org.br.

Recebido em: 13/05/2009. Aprovado em: 30/10/2009. 

e vimos a sua glória, como a glória do unigênito do Pai, cheio de graça e de verdade.

\section{Introdução}

Nas últimas décadas, a temática da vida sexual vem se visibilizando na academia (e na sociedade) com relevo e importância (VANCE, 1995). Como nos lembra Foucault (1993a), isso se deve ao fato de, na modernidade, a sexualidade ser percebida como ponto de intersecção entre indivíduo e sociedade, operacionalizadora de problemáticas relacionadas à vida, à saúde, à doença $\mathrm{e}$ à morte - todas de especial interesse para políticas locais e globais. Temos na sexualidade um lugar estratégico para a gestão de populações.

Podemos dizer que foi numa perspectiva de refletir sobre os "perigos do sexo" que os anos de 1980 viram emergir no Brasil uma série de estudos sobre a sexualidade, sobre o "risco" das pessoas contraírem Infecçōes Sexualmente Transmissíveis (IST), dentre elas a Aids, e sobre a "gravidez na adolescência". Sem querer retomar aqui uma revisão de como evoluíram esses dois campos de estudos (vide CALAZANS, 2000; RIOS et al., 2002), gostaríamos de resgatar das perspectivas que consideramos mais promissoras, fruto dos debates dos últimos anos, uma sinalização que muitas vezes foi dita, mas que poucos levaram a sério na elaboração de pesquisas e/ou intervenções: a importância das culturas religiosas na construção da sexualidade na produção e reprodução da vida social (cf. especialmente MACHADO, 1996; RIOS, 2004; GIUMBELLI, 2005). Talvez, por que levaram a sério demais um velho vaticínio dos clássicos cientistas sociais da religião, que apontavam para um futuro desencantado, em que a religião cederia espaço à ciência (WEBER, 2004; BERGER, 1985). Mas o vaticínio não se cumpriu (pelo menos, não completamente) nem no Brasil, nem no mundo (HERVIEU-LÉGER, 1997; BERGER, 2001; MARIZ, 2001 e 2006; SOUZA, 2007).

Do mesmo modo, numa outra via de reflexão que tira o foco do sexual, vale recuperar outro importante ingrediente na proposta de se levar mais a sério o lugar da religiosidade quando se quer pensar (e promover) a saúde sexual: referimo-nos aos estudos sobre as relações políticas entre religiōes e Estado, que, dentre outras questões, sinalizam para a penetração das diferentes formas de 
religiosidade presentes no Brasil, seja nas instâncias de formulação das políticas públicas brasileiras, seja em recantos onde o Estado tem dificuldade de chegar (MACHADO, 2003; MAFRA, 2003; BOHN, 2004; MONTERO, 2006). É a partir deste quadro que queremos fazer girar a nossa discussão neste ensaio.

Ele consiste numa revisão dos significados da "sexualidade" no Ocidente, enfocando seu trato ao longo da história do cristianismo. Nossa expectativa é a de que possa iluminar as compreensões atuais sobre as questões referentes à sexualidade, dentro e fora dos contextos religiosos do Brasil contemporâneo. Questôes, lembramos, de especial interesse para os preocupados com velhas e novas problemáticas localizadas no campo do que se tem denominado de direitos sexuais e reprodutivos, com rebatimentos no campo da saúde pública.

\section{O corpo cristão: "na minha carne, não habita bem algum"}

Corpo e Espírito são temas-chave nos discursos religiosos cristãos, articulados quase sempre por uma perspectiva teleológica de "salvação", neste ou no "outro mundo". É certo que visões de mundo e de "outro mundo" variam de denominação a denominação. Talvez o que não varie, nas diferentes tradições de fundo cristão, é a existência de uma série de técnicas de poder, incorporadas enquanto técnicas de $s 2^{2}$ (FOUCAULT, 2004), que se propõem, através de açōes sobre o corpo, viabilizar o alcance de estados ideais de "santidade" (nas múltiplas definições que cada religião dá ao termo). Outra característica que perpassa as várias tradições cristãs é que nelas, as técnicas de si, em menor ou maior grau, vão incidir e refletir sobre as implicaçôes morais a propósito do que os humanos fazem com os desejos e as sensaçôes prazerosas do baixo corporal, ${ }^{3}$ para si mesmos e para a obra divina.

Não obstante, vale fazer uma ressalva: no manual de técnicas de si cristão, a Bíblia, em nenhum momento desejo sexual, erotismo ou sexualidade aparecem assim nomeados. ${ }^{4}$ Estas categorias são recentes na história do Ocidente, mas o referente aos quais estes termos remetem - grosso modo, o contato real ou desejado entre entes com implicações prazerosas e afetivas - são, sim, falados. A categoria êmica utilizada é carne.

Neste contexto, o corpo-carne, do qual São Paulo foi um dos principais comentadores do cristianismo nascente, ${ }^{5}$ parece se afigurar como importante categoria de entendimento do sexual e do que se deve com ele fazer. Sem nenhuma pretensão de exegese teológica, vejamos então como a carne aparece 
no Novo Testamento, mais especificamente nas epístolas paulinas. Nelas o termo torna-se emblemático, sendo retomadas, séculos depois, pelos especialistas cristãos organizados numa estrutura de igreja, que será dominante na Europa e daí disseminada pelo mundo nas práticas de colonização (ARIÈS, 1987).

\section{O Verbo e a carne}

É na articulação entre carne e Verbo que João (1:14), no início de seu evangelho, se refere à vinda do Cristo. Não obstante, se, para Deus, o contato com a carne não envolve perigo, é demonstração de Sua glória, para os humanos as coisas não funcionam bem assim. Mateus (26,41), já alertaria sobre os riscos da carne: "Vigiai e orai, para que não entreis em tentação; na verdade, o espírito está pronto, mas a carne é fraca”.

Em Paulo, a noção de carne é ainda mais contundente, ela não será apenas fraca, mas especialmente perigosa para a obra divina: "Porque eu sei que em mim, isto é, na minha carne, não habita bem algum; e, com efeito, o querer está em mim, mas não consigo realizar o bem." (Romanos 7:18). De certa forma, ele ajuda a mais explicitamente definir para o ideário cristão o que será para o Ocidente, a "eterna" luta do Espírito contra o corpo, entendido aí como carne. "Porque a carne cobiça contra o Espírito, e o Espírito contra a carne; e estes opõem-se um ao outro, para que não façais o que quereis." (Gálatas 5:17).

Ainda que em muitos momentos carne e corpo se confundam na obra paulina, como uma e mesma coisa, em outras passagens Paulo parece querer fazer uma distinção do referente para os dois conceitos: "Porque, se viverdes segundo a carne, morrereis; mas, se pelo Espírito mortificardes as obras do corpo, vivereis." (Romanos 8:13). Esta distinção parece sugerir a existência de algo mais específico à própria a noção de carne: "Porque as obras da carne são manifestas, as quais são: adultério, prostituição, impureza, lascívia” (Gálatas 5:19). De outro modo, enquanto o corpo parece remeter à própria condição de existência humana no mundo, sendo, inclusive, em alguns momentos positivado enquanto templo do Espírito Santo, ${ }^{6}$ a carne, que habita este corpo, diz daquilo que pode afastar a pessoa do paraíso prometido. Em Gálatas, e em outros momentos de sua obra, ${ }^{7}$ ele nomeia uma série de inclinações carnais que, mais tarde, na história do cristianismo, se tornaria objeto de reflexão para os defensores da vida monástica (FOUCAULT, 1987). 
Segundo Ariès (1987), em Paulo os pecados se dividem em cinco grandes categorias: os pecados contra Deus, contra a vida do homem, contra o seu corpo, contra os bens e as coisas, e os da palavra. Passemos diretamente para a categoria que aqui nos interessa, os pecados contra o corpo-carne, dividida em quatro subgrupos:

O primeiro subgrupo é constituído pelos prostituídos: fornicarii (em grego: pornoi). O segundo é o dos adúlteros, isto é, os que seduzem a mulher do outro - e as mulheres que se deixam seduzir. [...] O terceiro grupo é o dos molles (malakoì): é particularmente interessante para nós e revela algo importante e novo ${ }^{8}[\ldots]$ é, um conjunto de práticas que retardam o coito, quando não o evitam, com a finalidade de gozar melhor e por mais tempo: exclusivamente o prazer. [...] São Paulo cita ainda os masculorum concubitores, os homens que dormem juntos. [...] a homossexualidade, difundida no mundo helenístico e considerada normal, tornava-se um ato abominável e proibido. (ARIĖS, 1987, p. 51-52)

Sintetizando, Ariès (1987, p. 52) sublinha que a partir das epístolas paulinas surge "uma moral sexual, pecados contra o corpo, devidos ao uso ou abuso das inclinações sexuais, dir-se-á a concupiscência."” Emerge uma percepção de prazer sexual enquanto algo que, ainda que devesse estar ao serviço do "multiplicai", se revela enquanto um gozo capaz de independência deste mandamento. Do mesmo modo, um impulso que, livre de uma realização em termos de práticas, preexiste guardada no corpo, mas a qualquer momento podendo ser capaz de fazê-lo agir em seus próprios termos, de modo contrário aos mandamentos divinos. Está inaugurado, conforme Foucault (1993b), o desejo sexual.

Situado, com São Paulo, o ideário que orientará a moral sexual cristã, dele derivará um conjunto inicial de técnicas de si: as prescrições para tornar as pessoas afeitas à obra divina - sobre as quais retomaremos mais adiante. Por ora, vale pontuar que é nessa linha que, nos primeiros séculos do cristianismo e no contexto da formação do discurso monástico católico, as inclinações carnais serão retomadas no âmbito do que se chamou, de forma um tanto mais sistematizada, de "oito espíritos do mal" ou simplesmente "vícios" (FOUCAULT, 1987).

Comentando a formação dos princípios monásticos cristãos na obra de Cassiano (370-435), Foucault (1987) aponta como os vícios, aos pares, têm entre si relações particulares de aliança e continuidade: orgulho e vanglória, preguiça e acedia, avareza e cólera, fornicação e gula. Suas interligações se fazem acompanhar de uma hierarquização, de modo que o último dos pares citados ganha um relevo especial. O vício da fornicação assumirá lugar privilegiado com relação aos outros 
vícios, num encadeamento causal, onde a gula acende a fornicação; esse primeiro par engendra a avareza (apego aos bens terrenos) fazendo nascerem rivalidades, disputas e ira; produz-se, então, o abatimento da tristeza que provoca aversão pela vida monástica como um todo e a acedia. Destarte, a implicação lógica é: jamais se poderá vencer um vício se não se triunfar sobre àquele sobre o qual está apoiado - em última instância, se não se triunfar sobre a carne.

Ainda sobre a fornicação: "não pode ser desenraizada sem 'a mortificação corporal, vigílias, jejuns, o trabalho que mói o corpo'. O que não exclui [...] o combate que a alma deve travar contra si mesma, pois fornicação pode nascer do pensamento, de imagens e de lembranças" (FOUCAULT, 1987, p. 27-28). Em contraposição, o combate contra a gula deve ser comedido, haja vista que não podemos renunciar, de todo, ao alimento. Negá-lo totalmente, até a morte, seria também pecado. Do mesmo modo, diremos, algo da ordem da fornicação precisa existir, se não entre os monges, pelo menos entre os fiéis leigos, de modo que a reprodução social aconteça e a ordenação do "crescei e multiplicai" se cumpra.

Vale então destacar que, e no que tange às implicações das práticas e inclinações carnais para o que hoje chamamos reprodução social, é o mesmo Paulo, tão preocupado com as questôes carnais dos cristãos, e mesmo que considerasse o ideal da castidade, ${ }^{10}$ quem vai oferecer os recursos para situar a vida sexual dentro do casamento, bem como as dos solteiros e dos viúvos, como apresentado em 1 Coríntios 7:1-40. ${ }^{11}$

\section{O pastorado}

Também é importante refletir sobre quais são, e como operam, os mecanismos para que as diretrizes do cristianismo se cumpram em seus seguidores. Em Omnes et Singulatim, Foucault $(2006)^{12}$ discute o poder exercido pelo cristianismo sobre os adeptos, através do dispositivo do pastorado - em outras palavras, as tecnologias de poder feitas tecnologias de si. A metáfora do cuidado prestado pelo pastor ao seu rebanho, para falar da gestão de comunidades não é uma invenção do cristianismo. Ela vai aparecer entre gregos e hebreus, ${ }^{13}$ mas vai ganhar novo sentido no contexto cristão.

"Na concepção cristã, o pastor deve prestar contas - não só de cada uma das ovelhas, mas de todas as suas ações, de todo o bem ou o mal que são capazes de realizar, de tudo o que lhes acontece" (FOUCAULT, 2006, p. 367). O 
cristianismo institui, então, um intercâmbio e uma circulação complexos de pecados e de méritos entre cada ovelha e seu pastor:

O pecado da ovelha é também imputável ao pastor. [...] ajudando seu rebanho a encontrar a salvação, o pastor encontrará também a sua. Mas, salvando suas ovelhas, corre o risco de se perder; se quiser salvar a si mesmo, deve necessariamente correr o risco de estar perdido para os outros. Se ele se perder, é o rebanho que ficará exposto aos maiores perigos. (FOUCAULT, 2006, p. 367)

Estes paradoxos ajudam a acentuar o que será sublinhado por Foucault (2006) como uma complexidade dos vínculos morais associando o pastor a cada membro de seu rebanho, individualmente. Afinal, "Não basta saber em que estado se encontra o rebanho. É necessário também conhecer o de cada ovelha”. Esses vínculos não dizem apenas respeito à vida pública dos indivíduos, mas também aos seus atos nos ínfimos detalhes: "o pastor deve ser informado das necessidades de cada componente do rebanho, e [...] deve saber o que passa na alma de cada um, conhecer seus pecados secretos, sua progressão no caminho da santidade". (FOUCAULT, 2006: 368-369)

Para dar conta desse conhecimento necessário para a condução do rebanho, o cristianismo irá reelaborar dois elementos advindos do mundo helênico: o exame de consciência e a direção de consciência.

O exame de consciência, sabe-se, era comum entre os pitagóricos, os estóicos e os epicuristas, que nele viam um meio de prestar contas cotidianamente sobre o bem e o mal realizado com relação aos seus deveres. Assim, se podia medir sua progressão no caminho da perfeição, ou seja, o domínio de si e o império exercido sobre as próprias paixões. A direção de consciência era também predominante em certos ambientes cultivados, mas tomava então a forma de conselhos dados - e às vezes retribuídos - em circunstâncias particularmente difíceis: na aflição, ou quando se sofria de um golpe de sorte. (FOUCAULT, 2006, p. 369).

No pastorado cristão, o exame de consciência não terá o intuito de cultivar a consciência de si, mas permitirá a pessoa abrir-se inteiramente ao seu diretor: revelar-lhe as profundezas da alma. Já a direção de consciência se constituirá em uma ligação permanente: a ovelha não se deixará conduzir apenas no caso de precisar enfrentar algum passo perigoso; ela se deixará conduzir em cada instante. Para o cristianismo, diz Foucault (2006), há um vínculo entre a obediência total e o conhecimento de si, articulado e mediado pela confissão a alguém.

Foucault (2006) nos lembra, entretanto, que nos primeiros tempos do cristianismo, antes de se instalar a técnica da confissão - restrita à relação dual 
entre o pastor e a ovelha - era, o que chamaremos aqui de testemunho público, a principal forma de lidar com o pecado:

O exomologêsis era o ritual pelo qual um indivíduo se reconhecia como pecador e como penitente. Compreendia muitas características: primeiramente, o pecador possuía estatuto de penitente para um período que poderia ser de quatro a dez anos, e esse estatuto afetava o conjunto de sua vida. [...] sua vida não se pareceria mais às dos outros. Mesmo depois da reconciliação, certas coisas lhe permaneceriam proibidas: por exemplo, não poderia se casar ou tornar-se pai. (FOUCAULT, 2006, p. 369)

Finalmente a última transformação - para Foucault (2006, p. 370) talvez a mais importante:

todas estas técnicas cristãs de exame, de confissão, de direção de consciência e de obediência têm uma finalidade: levar os indivíduos a trabalhar na sua própria 'mortificação' neste mundo". Neste contexto, a mortificação ou penitência, enquanto forma de relação para consigo mesmo, assume o sentido de "renúncia a este mundo e a si mesmo: uma espécie de morte cotidiana. Morte que é considerada por dar a vida no outro mundo.

O dispositivo estava, então, pronto: a centralidade dos pecados da carne, no modo como se situam na ordem do mundo e em suas implicações para os indivíduos; o jogo do controle para "saber" e o da disciplina para "fazer", por meio do pastorado, os cristãos responsáveis por si e pelos outros. E, não só em suas vidas públicas e em seus atos: o imperativo do exomologêsis e/ou da confissão torna possível "desemboscar tudo o que de fornicação secreta possa se ocultar nos mais profundos vincos da alma” (FOUCAULT, 1987, p. 28).

\section{Outras vozes: artimanhas da carne}

Concordando com Foucault (1993a, 1993b, 2006, 1987) e Ariès (1987), o sexual ou a carne parece assumir, no ideário cristão, uma centralidade que, de algum modo, chega aos dias atuais, atualizadas, por exemplos, nas polêmicas sobre a sexualidade dos jovens, ou o uso da camisinha entre casados e não-casados. Mas deixando para outro momento uma discussão sobre a utilização deste ideário nos tempos atuais (cf. RIOS et al., 2008b; RIOS et al., 2008a), precisamos voltar no tempo a fim de buscar, por outras vozes sobre o corpo e sobre a carne.

Refletindo sobre os muitos particularismos do cristianismo e o modo como os preceitos morais cristãos se atualizariam ao longo dos muitos séculos de cristianismo na Europa, Flandrin (1987, p. 146) questiona se haveria "adesão verdadeira e profunda à doutrina cristã ou somente manifestação externa de respeito que só visava salvar as aparências". 
Tomando o cristianismo francês como exemplo, Flandrin (1987) lembra que, em geral, a leitura da baixa fecundação dos casamentos, do aumento do número de nascimentos ilegítimos e das concepções pré-nupciais entre os camponeses em meados do século XVIII aos nossos dias, destacam como causa o processo de descristianização deste grupo. Por outro lado, historiadores afeitos à Reforma Católica afirmam que as camponesas francesas não haviam sido verdadeiramente cristianizadas antes do século XVII; até então, estas teriam permanecido profundamente pagãs. Flandrin (1987, p. 147) objeta:

Não creio que essas noções sejam operatórias quando tratamos da história das mentalidades e dos comportamentos e não de propaganda ideológica. Os franceses, inclusive os do campo, foram cristianizados desde a Alta Idade Média e deram desde então todo tipo de provas de sua fé, provas inequívocas, do seu ponto de vista: participação ao culto, pagamento do dízimo e de oferendas piedosas, peregrinações, cruzadas, heresias, guerras de religião. O que os propagandistas da Reforma Católica chamaram de paganismo me parece antes um cristianismo particular, caracterizado por seu arcaísmo e pela marca das mentalidades camponesas.

Os camponeses eram cristãos à sua maneira há um milênio, como os outros grupos sociais eram cada qual a seu modo. Os nobres, que quando não faziam a guerra, faziam amor com as damas da corte, eram mais cristãos? Mais bem cristianizados? $\mathrm{E}$ os burgueses, cuja virtude cardinal era a avareza? E os conquistadores, cuja avidez e cujas atrocidades são bem conhecidas, mas que, por outro lado, se recusavam categoricamente a ter relações sexuais com as mexicanas que lhes eram oferecidas antes que fossem batizadas [...]. Definitivamente, cada qual era cristão à sua maneira, que nunca era a dos teólogos, nem a nossa.

O que gostaríamos de apontar, junto com Flandrin (1987), éque, seéimportante refletirmos sobre os "núcleos duros" da cultura religiosa, suas materializações em textos, que de certo modo "fixam" um ideal prescritivo de cristandade, isso não significa dizer que ontem e hoje redescrições da norma tenham deixado de existir na prática. Não só redescrições idiossincráticas, próprias ao modo como o sujeito singular articula o preceito no seu processo de tornar-se humano; também existiram outras linhagens conceptuais coletivamente compartilhadas, outras éticas concorrentes, que se somaram para apreender a carne.

Lembramos aqui de Bakhtin (1996), especialmente sua abordagem de A cultura popular na Idade Média e no Renascimento: o contexto de François Rabelais. ${ }^{14}$ Por meio das obras de Rabelais, produzidas no momento da passagem da Idade Média para o Renascimento e baseadas nos acontecimentos do cotidiano, Bakhtin (1996, p. 3) nos descreve o outro lado da moeda (ou 
da carne, sendo inevitável o trocadilho), aquilo que se passa ao largo do, ou atravessa o, confessionário. O que os cristãos viviam nas ruas e nas igrejas, mas que não se expressavam positivamente na literatura eclesiástica: "O mundo infinito das formas e manifestaçôes do riso (que) opunha-se à cultura oficial, ao tom sério, religioso e feudal da época." Prossegue o autor:

Dentro da sua diversidade, essas formas e manifestações - as festas públicas carnavalescas, os ritos e cultos cômicos especiais, os bufóes e tolos, gigantes, anões e monstros, palhaços de diversos estilos e categorias, a literatura paródica, vasta e multiforme, etc. - possuem uma unidade de estilo e constituem parte e parcelas da cultura cômica popular, principalmente da cultura carnavalesca, una e indivisível. (BAKHTIN, 1996, p. 3-4)

Bakhtin (1996) descreve cristãos que festejavam a carne e brincavam com aquilo que a Igreja temia, rejeitava ou simplesmente queria manter sob seu controle. Mostra um povo que ironizava e ria das coisas sagradas:

Não se trata naturalmente de ritos religiosos, no gênero, por exemplo, da liturgia cristã, à qual eles se relacionam por laços genéticos distantes. O princípio cômico que preside aos ritos do carnaval, liberta-os totalmente de qualquer dogmatismo religioso ou eclesiástico, do misticismo, da piedade, e eles são além disso, completamente desprovidos de caráter mágico ou encantatório (não pedem nem exigem nada). Ainda mais, certas formas carnavalescas são uma verdadeira paródia do culto religioso. [...] Elas pertencem à esfera particular da vida cotidiana. (BAKHTIN, 1996, p. 5-4)

Ele apresenta uma cultura do cotidiano que, ainda que se articulasse com elementos da cultura religiosa, os indexava em seus próprios termos. Ela invertia o valor que a segunda queria lhe atribuir. Referimo-nos em especial à carne, profundamente exaltada no que o autor denominou "princípio da vida material e corporal: imagens do corpo, da bebida, da comida, da satisfação de necessidades naturais, e da vida sexual (BAKHTIN, 1996, p. 16).” Está-se no âmbito do realismo grotesco, sistema de imagens onde o cósmico, o social e o corporal estão ligados numa totalidade viva e indivisível, constituindo um conjunto alegre e benfazejo. Nele há o rebaixamento - a transferência para o plano material e corporal - de tudo que é elevado e espiritual, ideal e abstrato.

Neste contexto até a Bíblia - manual de técnicas de si dos cristãos - era parodiada, extraindo-se do texto sagrado os detalhes materiais e corporais degradantes e terra-a-terra. Está-se no âmbito da degradação vivificante, onde o baixo corporal, os órgãos genitais, o ventre e o traseiro ganham suas melhores e mais positivas expressões. Assinala o autor: 
Degradar significa entrar em comunhão com a vida da parte inferior do corpo, a do

ventre e dos órgãos genitais, e portanto, com atos como o coito, a concepção, a gravidez, o parto, a absorção de alimentos e a satisfação das necessidades naturais. A degradação cava o túmulo corporal para dar lugar a um novo nascimento. E por isso não tem somente um valor destrutivo, negativo, mas também um positivo, regenerador: é ambivalente, ao mesmo tempo negação e afirmação. (BAKHTIN, 1996, p. 19)

Podemos dizer que, nesse contexto, fornicação e gula, sem perder sua centralidade para a vida humana, tornam-se objetos de outra forma de técnicas de si: a do excesso que regenera e recria o mundo. Não obstante, esta, e de modo inusitado, ao mesmo tempo em que nega a distinção entre carne e Espírito, a reafirma. Seja porque a "gramática" utilizada é a mesma, seja porque o riso só pode surgir na medida em que a ordem, que supostamente todos devem obedecer, está sendo desestabilizada, está sendo objeto escancarado de burla e de blasfêmia. E para que o riso continue a existir, no final das contas, a "ordem” deve preponderar - assim se há subversão, concomitantemente há reiteração da disciplina bíblica.

\section{O corpo e a sexualidade: a carne feita risco nos dias atuais}

Da Igreja nascente aos dias atuais, o cristianismo "cresceu e se multiplicou". Ao longo dos séculos, disputas sobre os sentidos da letra dos primeiros apóstolos criaram fraturas, cismas, reformas e contra-reformas. ${ }^{15} \mathrm{E}$ se a religiosidade, como se pensava, não foi erradicada do mundo moderno (BERGER, 1985 e 2001), podemos dizer que são 20 séculos ao longo dos quais o cristianismo influencia e é influenciado por outros modos de conduzir técnicas de poder e de si na formação e manejo de indivíduos e populações. Assim, ainda que o nosso foco aqui esteja nos dispositivos religiosos cristãos na apreensão do corpo e da carne, não podemos desconsiderar outros dispositivos institucionais no diálogo com os primeiros. No caso contemporâneo, o Estado laico tem-se apresentado como uma instituição de onde estes dispositivos são mais fortemente elaborados - dele não escapando nem mesmo a tentativa de controle sobre o que é dito e feito pelas diferentes religiões.

Mas, sublinhamos, não devemos pensar que estes dois regimes de intervir nos indivíduos e grupos para constituir a sexualidade e a reprodução social - o religioso e o estatal - se encontram tão afastados e dicotômicos, como muitas vezes é pensado. Lembremos, com Weber (2004), que vem da própria "ética religiosa" (protestante) muito do que faz o "espírito" que possibilitou o capitalismo moderno e o Estado burguês se constituirem; não apenas como um modo de 
operar economicamente, mas um verdadeiro sistema cultural, ou seja, capaz de engendrar pessoas afeitas e prontas para reproduzi-lo:

[...] a ascese puritana - como toda ascese "racional" - trabalhava com o fim de tornar o ser humano capaz de enunciar afirmativamente e fazer valer, em face dos "afetos", seus "motivos constantes", em particular aqueles que ela mesma lhe 'inculcava': - com o fim, portanto, de educá-lo como uma "personalidade", neste sentido da psicologia formal. Poder levar uma vida sempre alerta, consciente, clara, ao contrário do que se fala em muitas das representaçôes populares, era meta; eliminar a espontaneidade do gozo impulsivo da vida, a missão mais urgente; botar ordem na conduta de vida de seus seguidores, o meio mais importante da ascese. Todos esses pontos de vista, que são decisivos, encontram-se estampados nas regras do monasticismo católico tanto quanto nos princípios de conduta de vida calvinistas. [...] Fácil captar, por outro lado, em que ponto se dava o contraste entre a ascese calvinista e a medieval: na supressão dos cosilia evangélica e, com isso, na transformação da ascese em ascese puramente intramundana. (WEBER, 2004, p. 108-109)

Segundo Weber (2004), a reforma protestante viria, paulatinamente, mudar os termos do que seria necessário para alcançar-se o outro mundo: eliminação da magia como meio de salvação; supressão das "mortificações corporais", que dará lugar a ascese via o trabalho neste mundo; permissão do acúmulo, ainda que austero, de bens, enquanto demonstração da fruição da graça. Esse novo contexto simbólico constituirá solo propício para o desenvolvimento do racionalismo burguês. A partir de então o caminho está aberto para uma perspectiva secular de estar no mundo, para a emergência de um Estado laico dissociado da magia e religião - ao menos pretensamente. ${ }^{16}$

No que concerne ao nosso objeto de interesse, Foucault (1993a e 1993b) lembra que, no processo de modernização do ocidente, a sexualidade deixa de ser percebida como mediadora para o acesso ao "outro mundo". Não obstante, como já apontamos no início deste ensaio, será apreendida como operacionalizadora de questôes relacionadas à vida e à morte, lugar estratégico para a gestão de populações.

Estamos no âmbito daquilo que Foucault (1995) denominou de biopoder, o operador da articulação entre tecnologias disciplinares e biopolíticas que se expandiu e generalizou por todo corpo social durante o século XIX. O que vai caracterizá-lo é a força dos aparelhos biomédicos integrando-se aos aparatos administrativos estatais, com funções reguladoras das populações.

No que se refere à disciplinarização dos sujeitos, Foucault (1995) aponta que, com a emergência do liberalismo, as condutas serão, mais e mais, apreendidas numa flexibilidade aparente das estruturas sociais. Modo operativo que garante 
o controle, intensificando-o e ampliando-o por todo corpo social; ao mesmo tempo em que os indivíduos são significados como "livres para escolher". Nesse processo, a noção de "segurança" constitui-se como categoria chave para a formação de sujeitos pretendidos pelas normas do Estado - componente dominante da moderna racionalidade governamental. Neste quadro, segurança significará "a tentativa de banir qualquer possibilidade de riscos virtuais, prováveis e calculáveis através de novas estatísticas de probabilidade torna-se ainda mais potente." Um ideal que "rege o sonho do absoluto controle dos acidentes e o mito da razão calculada", onde o risco "se encontra em tudo que o indivíduo ainda não aprendeu a controlar” (CALIMAN, 2006, p. 207).

Ainda que as marcas da gestão religiosa dos rebanhos tenham sido supostamente apagadas, impossibilitando que muitas vezes se veja o pastorado na operacionalidade do Estado laico, vale a pena apontar, não apenas para as transformações, mas também para as continuidades na forma do ocidente constituir a carne/erotismo, ou mais amplamente a vida em sociedade. Assim, Sahlins (2004) mostrará como as concepções cristãs, como estruturas de tempo longo, continuam presentes orientando pensamentos e ações. O supracitado autor sugere que noções como as de providência divina e de cidade celestial serviriam de base para pensar e constituir o Estado moderno; do mesmo modo a oposição entre carne e espírito ecoa sub-repticiamente, mesmo nas perspectivas ditas científicas que, apartando corpo e mente, fazem do primeiro algo recorrentemente perigoso. O Espírito feito razão, contemporaneamente, embasa as ideologias da "escolha racional" que sustentam o individualismo, ou, mais amplamente, o modo de interpretar comportamentos individuais e coletivos - ainda no campo do cálculo, do risco ou da segurança como indicamos acima.

Ainda sobre as articulações entre perspectivas religiosas e laicas na gestão de populações, Foucault (2006) sublinha:

Podemos dizer que o pastorado cristão introduziu um jogo que nem os gregos nem os hebreus haviam imaginado. Estranho jogo cujos elementos são a vida, a morte, a verdade, a obediência, os indivíduos, a identidade; jogo que parece não ter relação alguma com o da cidade que sobrevive através do sacrifício dos seus cidadãos. Combinando estes dois jogos - o jogo da cidade e do cidadão e o jogo do pastor e do rebanho - no que denominamos os Estados modernos, nossas sociedades revelaram-se verdadeiramente demoníacas. (FOUCAULT, 2006, p. 369)

Assim, nos tempos atuais, no momento mesmo em que a carne parece perder força discursiva para se pensar a salvação da alma, o desejo sexual (res) 
surge triunfante enquanto fator chave para o cálculo dos riscos, e salvação da sociedade. Mais uma vez, um lugar privilegiado de intervenção da coletividade sobre o indivíduo, onde o manual das técnicas de si deixa de ser a Bíblia, ou os manuais de higiene sexual dos eugenistas, os tratados dos sexólogos e os escritos dos psicanalistas dos séculos XIX e XX. Agora os manuais são as "Cartilhas de Sexo Seguro" - sempre incluindo um capítulo sobre métodos contraceptivos!

Com efeito, considerando a inspiração de Foucault (2006) no parágrafo supracitado, podemos seguir uma das muitas linhas interpretativas que o termo demoníaco oferece e nos perguntar se não seria este (o demoníaco) a condição de ser sujeito (d)à carne - entendida como concupiscência no ideário religioso, ou como o erótico no ideário científico moderno? A "essência" do sexual que se nega à disciplina. Afinal, a força erótica, essencializada pela religião e pela bio-medicina, se interpõe e subverte a toda tentativa de disciplina (cf. RIOS et al., 2008b).

Como mostram Rios, Paiva, Maksud et ali (2008b), de algum modo o "vigiai e orai" das escrituras bíblicas continua estratégia para manter, adeptos/cidadãos, a serviço da obra (divina e/ou do Estado), bem longe das tentaçôes. Neste contexto, é interessante notar que para o Modelo Transteórico (PROCHASKA; VELICER, 1997), o mais citado entre as abordagens individualistas para a promoção da saúde, as mudanças de comportamento devem ser compreendidas e estimuladas a partir de cinco construtos: estágios de mudança, processos de mudança, balanço decisório, autoeficácia e tentação. Nesse contexto teórico, e no caso das intervenções em saúde sexual e reprodutiva, a tentação, enquanto desejo sexual, assume o lugar da carne, que teima a desestabilizar os cálculos, solicitados pelos técnicos aos indivíduos como forma de se manterem seguros e saudáveis.

\section{Mais algumas palavras}

Nosso sobrevoo pelas inflexôes do pensamento cristão sobre as sensações prazerosas e desejantes do baixo corporal foi feito com a clareza de que não conseguiríamos cobrir com maior profundidade um escopo histórico tão vasto. Bem mais modéstia foi a nossa pretensão: no momento mesmo em que as religiōes voltam, mais que nunca, à cena das preocupações de governantes e acadêmicos (DUARTE et al., 2009), mobilizar investimentos em pesquisas que abordem suas interferências no plano da construção das sexualidades. Nesse bojo, chamar atenção para um conjunto de conceitos, aqui no mais das vezes apenas apontados, 
que necessitam de maior aprofundamento e articulações na perspectiva de melhor compreender a influência do ideário sobre a carne no modo como na atualidade se vem procedendo, a partir de diferentes lugares institucionais, a gestão de indivíduos e populações na lida com a sexualidade. ${ }^{17}$

Não obstante, e de modo um tanto inusitado, nesse processo de pensar o lugar da carne na história do ocidente fomos levados um pouco mais longe em nossas reflexões, as quais, gostaríamos de compartilhar aqui, na perspectiva de oferecer mais recursos para montar essa agenda de pesquisas que gostaríamos de ver se configurar.

Assim, as leituras de Ariès (1987), Foucault (1993a, 1993b, 2006, 1987), Bakhtin (1996), Sahlins (2004), Weber (2004) - e outros autores os quais chamamos para conosco dialogar neste ensaio - nos fizeram questionar algo do próprio princípio epistemológico que nos conduz: o construcionismo. Fizeramnos indagar, junto com Vance (1989), sobre o que estamos tomando como construído quando falamos da construção social da sexualidade; sobre o lugar do corpo neste campo epistemológico; e sobre qual a definição daquilo que chamamos de sexualidade, de modo tão corriqueiro e pouco refletido dentro do próprio campo no qual nos localizamos.

Não teremos espaço, neste texto, para aprofundar estas questôes à luz da história da carne. Ainda assim, queremos aproveitar as indagações da autora e tecer alguns comentários adicionais sobre a densidade histórica do sexual. Para seguirmos adiante, refizemos as questôes daquela autora nos seguintes termos: Teria a sexualidade capacidade de produzir, ela mesma, mudança nas crenças e concepções que orientam os seres humanos no mundo?

Connell e Dowsett (1999) respondem de modo um tanto singular a tal questão. Eles propõem a sexualidade como algo que vai além de mais um domínio sobre o qual a sociedade dará sentido. Eles subvertem tanto os termos das teorias essencialistas como os dos chamados construcionistas radicais, apontando a centralidade da sexualidade para a própria construção da sociedade:

Society does not simply construct sexuality, society is constructed sexually. Once this is accepted we cannot be content with images of moulding, regulating, controlling. We must think of sexuality in terms of historically dynamic patternings of practice and relationship, which have considerable scope and power. (CONNELL; DOWSETT, 1999, p. 190)

Nessa linha, pensamos ser importante considerar a densidade fenomênica da interação sexual: capaz de gerar novas vidas e, se considerarmos os agravos em 
saúde (e direitos) referidos ao sexual, também mortes - sublinhamos, tanto nos níveis individuais quanto nos níveis coletivos da vida social. Sem desconsiderar o fato de que um acontecimento, qualquer que seja, só ganha sentido quando culturalmente significado, é importante lembrar que, em determinados contextos e/ou momentos históricos, acontecimentos sexuais, em suas múltiplas consequências (de prazer e de sofrimento), são capazes de provocar riscos empíricos (SAHLINS, 1990) que chamem pela mudança sociocultural.

O próprio Sahlins (1990) vai mostrar como acontecimentos sexuais foram fundamentais na mudança cultural que se desenvolveu no Havaí com a chegada do capitão Cook na Polinésia. Contemporaneamente, podemos pensar no surgimento da AIDS como um importante exemplo do que estamos querendo argumentar. Ainda que sujeita a inumeráveis interpretações culturalmente embasadas, não se pode negar seu poder de se oferecer como risco empírico às organizaçôes sociais, com uma alta capacidade mobilizadora, desestabilizadora e modificadora de trajetórias individuais e coletivas - inclusive nas ciências, nas mais diversas culturas sexuais e, mais amplamente, na própria história do norte e do sul do mundo (cf. VANCE, 1995).

Nessa linha, estudos de caso etnograficamente embasados - os quais vêm sendo construídos entre católicos, evangélicos e afro-brasileiros ao logo do projeto onde este ensaio se insere como um dos seus produtos - apontam o quanto HIV, em sua dimensão de infecção sexualmente transmissível, vem afetando as diferentes tradiçōes religiosas presentes no Brasil. ${ }^{18} \mathrm{O}$ que se observa é que, se, por um lado, preceitos e dogmas próprios à cada tradição (e mesmo as denominações religiosas dentro de uma mesma tradição) possibilitam modos próprios de lidar com a epidemia (em relação ao acolhimento aos soros-positivos e à prevenção); por outro, a própria possibilidade de infecção pelo HIV se oferece como acontecimento e risco empírico a desafiar aqueles mesmos ideários, articulados pelas estruturas conceptuais próprias à cada forma de religiosidade. Assim, tem-se presenciado a operação de um conjunto dissonante de processos de mudança, fruto do diálogo entre instâncias religiosas e laicas da sociedade brasileira, interpeladas pela epidemia em curso. Todas de certo modo convergindo para o sexual, ainda que disputando sentidos sobre a sua "verdade" e sobre as suas implicaçôes para a ordem do mudo e a reprodução social; e para além do que se tem conceituado mais comumente como sexualidade - nos referimos às relações de gênero, etárias, econômicas etc. 
Tomando um dos marcadores acima apontados a título de exemplo, e pensando no contexto brasileiro, apontamos os efeitos do HIV/Aids na formação de políticas públicas de acesso da população (mais especificamente, dos afetados pelo HIV) aos aparatos de saúde e de previdência social para sujeitos e arranjos sociais (famílias formadas a partir de casais homossexuais, por exemplo), em outros contextos sócio-históricos (melhor dizendo, sem a Aids), talvez inconcebíveis. Num outro plano, mais global, também está no HIV/Aids uma importante vertente de enfrentamento às premissas do capitalismo neoliberal contemporâneo, com a quebra de patentes, levada adiante pelo mesmo governo brasileiro.

Claro que não podemos creditar ao HIV/Aids, per si, as mudanças em andamento. Uma análise densa sobre tais mudanças considerará aspectos culturais e sócio-políticos constituintes no jogo que envolve instituições as mais diversas (OGs, ONGs, laboratórios, religiōes etc.), em diferentes níveis e planos. Não obstante, o que queremos apontar aqui é que a sexualidade, nestes e em outros fenômenos relacionados ao enfrentamento da epidemia, irá, indubitavelmente, aparecer como ponto de saída, de passagem e/ou de chegada para os embates se operando local e globalmente.

Por fim, os contextos teóricos e empíricos, acima esboçados, nos fazem pensar não apenas que o cristianismo desenvolveu uma forma própria de pensar o sexual, mas, e enfaticamente, numa construção sexual do próprio cristianismo. Seguindo esta linha, a partir dos autores australianos, e indo mais adiante, queremos finalizar este ensaio com mais uma indagação: em que medida a história passada e presente da carne cristã, em suas diferentes dimensões e implicações, pode nos levar a pensá-la como, ela mesma, constitutiva das categorias que orientam a história do ocidente?

\section{Referências}

ARIÈS, Philipe. São Paulo e a carne. In: ARIÈS, P.; BÉJIN, A. (Org.) Sexualidades ocidentais. São Paulo: Brasiliense, 1987. p. 50-53

BAKHTIN, Mikhail. A cultura popular na Idade Média e no Renascimento: o contexto de François Rabelais. São Paulo: Hucitec, 1996.

BERGER, Peter. A dessecularização do mundo: uma visão global. Religião e sociedade, v. 21, n. 1, p. 9-23, 2001. 
BERGER, Peter. $O$ dossel sagrado: elementos para uma teoria sociológica da religião. São Paulo: Paulinas, 1985.

BOHN, Simone. Evangélicos no Brasil: perfil socioeconômico, afinidades ideológicas e determinantes do comportamento eleitoral. Opin. Publica, v. 10, n. 2, p. 288-338, out. 2004, 2004.

CALAZANS, Gabriela. Cultura adolescente e saúde: perspectivas para investigação. In: OLIVEIRA, M. Cultura, Adolescência, Saúde: Argentina, Brasil e México. Campinas: CEDES/COLMEX/NEPO-UNICAMP, 2000. p. 44-97.

CALIMAN, Luciana Vieira. Dominando corpos, conduzindo ações: genealogias do biopoder em Foucault. In: JACÓ-VILELA, A. M.; CEREZZO, A. C.; RODRIGUES, H. (Org.). Cliopsyché: subjetividade e história. Juiz de Fora: Clio Edições Eletrônicas, 2006. p. 118-211.

CONNELL, Robert William; DOWSETT, Gary. The unclean motion of the generative parts: frameworks in western thought on sexuality. In PARKER, R.; AGGLETON, P. (Ed.) Culture, Society and Sexuality: a reader. London: University of London, 1999. p. 179-196.

DUARTE, Luiz Fernando et al. Valores religiosos e legislação no Brasil: a tramitação de projetos de Lei sobre temas morais controversos. Rio de Janeiro: Garamond, 2009.

FLANDRIN, Jean Louis. A vida sexual dos casados na sociedade antiga In: ARIÈS, Philipe;e BÉJIN, André. (Org.) Sexualidades ocidentais. São Paulo: Brasiliense, 1987. p. 135-152.

FOUCAUlT, M. As técnicas de si. In: Coletivo Sabotagem (org.) Por uma vida não-fascista (coletânea Michel Foucault Sabotagem), 2004. Disponível em: http:/www.scribd.com/ doc/337824/Foucault-Michel-Por-uma-vida-nao-facista\#/ Acesso em: 23 set. 2007.

FOUCAULT, Michel. Omnes et singulatim para uma crítica da razão política. In:

Ditos e escritos. V.IV: Estratégia, poder-saber. Rio de Janeiro: Forense Universitária, 2006.

FOUCAULT, Michel. O sujeito e o poder. In: DREYFUS, H.; RABINOW, P. Michel Foucault, uma trajetória filosófica para além do estruturalismo e da hermenêutica. Rio de Janeiro: Forense Universitária, 1995. p. 231-249.

FOUCAULT, Michel. História da sexualidade I: a vontade de saber. Rio de Janeiro: Graal, 1993a.

FOUCAULT, Michel. História da sexualidade III: o cuidado de si. Rio de Janeiro: Graal, 1993b.

FOUCAULT, Michel. O combate da castidade. In: ARIÈS, P.; BÉJIN, A. (Org.) Sexualidades ocidentais. São Paulo: Brasiliense, 1987. p. 25-38.

GIUMBELLI, Emerson (Org.). Religiāo e sexualidade: convicções e responsabilidades. Rio de Janeiro: Garamond, 2005.

HERVIEU-LÉGER, Daniële. Representam os surtos emocionais contemporâneos o fim da secularização ou o fim da religião? Religiāo e sociedade, v. 18, p. 31-47, 2001. 
MACHADO, Maria das Dores. Carismáticos e pentecostais: adesão religiosa na espera familiar. São Paulo: Autores Associados, 1996.

MACHADO, Maria das Dores. Existe um estilo evangélico de fazer política? In: BIRMAN, P. (Org.) Religião e espaço público. São Paulo: Altar Editorial, 2003. p. 283-308.

MAFRA, Clara. A habitação do morro: impressões de moradores de duas favelas do Rio de Janeiro sobre religião e espaço público. In: BIRMAN, P. (org.) Religião e espaço público. São Paulo: Altar Editorial, 2003. p. 201-220.

MARIZ, Cecília. Catolicismo no Brasil contemporâneo: reavivamento e diversidade. In: TEIXEIRA, F.; MENEZES, R. (Org.). As religióes no Brasil: continuidades e rupturas. Petrópolis: Vozes, 2006. p. 53-68.

MARIZ, Cecília. Secularização e dessecularização: comentários a um texto de Peter Berger. Religião e sociedade, v. 21, n. 1, p. 25-39, 2001. .

MAUSS, Marcel. Uma categoria do espírito humano: a noção de pessoa, a noção de eu. In: Sociologia e Antropologia. São Paulo: Cosac\&Naify, 2003. p. 367-397.

MONTERO, Paula. Religião, pluralismo e esfera pública no Brasil. Novos Estudos CEBRAP, n. 74, p. 47-65, mar. 2006, 2006.

PADGUG, Robert. Sexual Matters: On Conceptualizing Sexuality in History. In: PARKER, R.; AGGLETON, P. (Ed.). Culture, Society and Sexuality: a reader. London: UCL Press, 1999. p. 15-28.

PROCHASKA, James; VELICER, Wayne. The transtheoretical model of health behavior change. American Journal of Health Promotion, v. 12, n. 1, p. 38-48, 1997.

RIOS, Luis Felipe et al. Rumo à adultez: oportunidades e barreiras para a saúde sexual dos jovens brasileiros. Cad. CEDES, Campinas, v. 22, n. 57, p. 45-62, 2002.

RIOS, Luis Felipe. O Feitiço de Exu: um estudo comparativo sobre parcerias e práticas homossexuais entre homens jovens candomblesistas e/ou integrantes da comunidade entendida do Rio de Janeiro. Tese (Doutorado em Saúde Coletiva) - Instituto de Medicina Social, Universidade do Estado do Rio de Janeiro, Rio de Janeiro, 2004.

RIOS, Luis Felipe et al. Católicos, fidelidade conjugal e Aids: entre a cruz da doutrina moral e as espadas do cotidiano sexual dos adeptos. Debates do NER, v. 1, n. 14, p. 135-168, 2008a.

RIOS, Luís Felipe et al. Os cuidados com a "carne" na socialização sexual dos jovens. In: Psicologia em Estudo, Maringá, v.13, n. 4, ago./dez, p. 673-682, 2008b.

SAHLINS, Marshall. Cultura na prática. Rio de Janeiro: Editora UFRJ, 2004.

SAHLINS, Marshall. Ilhas de História. Rio de Janeiro: Zahar, 1990.

SEFFNER, Fernando et al. Respostas religiosas à Aids no Brasil: impressões de pesquisa acerca da Pastoral de DST/Aids da Igreja Católica. Ciencias Sociales y Religión / Ciências Sociais e Religiāo, n. 10, p. 159- 180, 2008. 
SOUZA, André. Igreja Católica e mercados: a ambivalência entre a solidariedade e a competição. Religiāo e sociedade, v. 27, n. 1, p. 156-174, 2007.

VANCE, Carole. A Antropologia redescobre a sexualidade: um comentário teórico. Physis: Revista de Saúde Coletiva, Rio de Janeiro, v. 5, n. 1, p. 7-31, 1995.

VANCE, Carole. Social Construction Theory: Problems in the History of Sexuality. In: ALTMAN, D. et al. (Ed.) Homosexuality, Which Homosexuality? London: Gay Men's, 1989. p. $12-34$.

WEBER, Max. A ética protestante e o espirito do capitalismo. São Paulo: Cia das Letras, 2004.

\section{Notas}

${ }^{1}$ As reflexões aqui apresentadas foram elaboradas no âmbito do projeto "Respostas Religiosas à Epidemia do HIV/AIDS no Brasil", que tem financiamento do U.S. National Institute of Child Health and Human Development, 1 R01 HD05118. Principal Investigador: Dr. Richard Parker - Columbia University). O estudo, de abrangência nacional, é realizado em quatro sítios específicos, nas seguintes instituições e com os respectivos coordenadores: Rio de Janeiro (Associação Brasileira Interdisciplinar de AIDS/ABIA - Dr. Veriano Terto Jr.); São Paulo (Universidade de São Paulo/USP - Dra. Vera Paiva); Porto Alegre (Universidade Federal do Rio Grande do Sul/UFRGS - Dr. Fernando Seffner) e Recife (Universidade Federal de Pernambuco/ UFPE - Dr. Luís Felipe Rios). O conteúdo é de inteira responsabilidade dos autores e não representa a posição oficial do Eunice Kennedy Shriver National Institute of Child Health and Human Development ou do National Institutes of Health. Informações adicionais sobre o projeto podem ser obtidas pelo e-mail religião@abiaids.org.br ou através do site www.abiaids.org.br. Queremos registrar nossos agradecimentos à Profa. Dra. Lady Selma Albernaz, pelos comentários e sugestôes no processo de elaboração deste texto.

${ }^{2}$ Vale destacar que Foucault (2004, p. 79) situa as técnicas de si no âmbito de um conjunto de práticas que os seres humanos utilizam para compreenderem aquilo que são. E prossegue tipificando-as: "No contexto dessa reflexão, trata-se de ver que essas técnicas se dividem em quatro grandes grupos, onde cada qual representa uma matriz da razão prática: 1) as técnicas de produção graças as quais podemos produzir, transformar e manipular objetos; 2 ) as técnicas de sistemas de signos, que permitem a utilização de signos, de sentidos, de símbolos ou de significação; 3) as técnicas de poder, que determinam a conduta dos indivíduos, submetendo-os a certos fins ou à dominação, objetivando o sujeito; 4) as técnicas de si, que permitem aos indivíduos efetuarem, sozinhos ou com a ajuda de outros, um certo número de operaçôes sobre seus corpos e suas almas, seus pensamentos, suas condutas, seus modos de ser; de transformarem-se a fim de atender um certo estado de felicidade, de pureza, de sabedoria, de perfeição ou de imortalidade".

${ }^{3}$ A expressão baixo corporal é utilizada por Bakhtin (1996) para se referir às partes do corpo comumente associadas aos prazeres do corpo, em especial àqueles de cunho sexual e, por isso, valoradas negativamente pelo cristianismo, mais especificamente o catolicismo medieval e renascentista, por ele estudado.

${ }^{4}$ Para esta afirmação, nos baseamos em consulta no site http://www.bibliaonline.com.br. Acesso em: 20 set. 2007. Nossa pesquisa se restringiu ao Novo Testamento. Destacamos também que as citaçôes bíblicas utilizadas são as disponibilizadas neste site.

${ }^{5}$ Para efeitos deste trabalho, não nos remeteremos à noção de carne no Velho Testamento, onde ela também é recorrente. 
6 "Ou não sabeis que o vosso corpo é o templo do Espirito Santo, que habita em vós, proveniente de Deus, e que não sois de vós mesmos?” (1 Coríntios, 6: 19).

7 "Exterminai, pois, as vossas inclinaçôes carnais; a prostituição, a impureza, a paixão, a vil concupiscência, e a avareza, que é idolatria;" (Colossenses 3:5-6).

${ }^{8} \mathrm{Na}$ tradução utilizada na Bíblia On line, mollities assume o significado de efeminado (cf. 1 Coríntios 6: 9). Áriès (1987) aponta para essa forma de traduzir o termo, mas, como vemos, argumenta em favor de traduzi-lo como lassidão, com o sentido de prazer sexual.

${ }^{9}$ Assim, adverte São Paulo em Romanos e em Gálatas: "Mas revesti-vos do Senhor Jesus Cristo, e não tenhais cuidado da carne em suas concupiscências." (Romanos 13:14). "E os que são de Cristo crucificaram a carne com as suas paixôes e concupiscências." (Gálatas 5:24).

10 "Porque quereria que todos os homens fossem como eu mesmo; mas cada um tem de Deus o seu próprio dom, um de uma maneira e outro de outra. Digo, porém, aos solteiros e às viúvas, que lhes é bom se ficarem como eu. Mas, se não podem conter-se, casem-se. Porque é melhor casar do que abrasar-se."(1 Corintios 7)

11 "Mas, por causa da prostituição, cada um tenha a sua própria mulher, e cada uma tenha o seu próprio marido. O marido pague à mulher a devida benevolência, e da mesma sorte a mulher ao marido. [...] Não vos priveis um ao outro, senão por consentimento mútuo por algum tempo, para vos aplicardes ao jejum e à oração; e depois ajuntai-vos outra vez, para que Satanás não vos tente pela vossa incontinência. Digo, porém, isto como que por permissão e não por mandamento. [...] Todavia, aos casados mando, não eu mas o Senhor, que a mulher não se aparte do marido. Se, porém, se apartar, que fique sem casar, ou que se reconcilie com o marido; e que o marido não deixe a mulher. Mas aos outros digo eu, não o Senhor: Se algum irmão tem mulher descrente, e ela consente em habitar com ele, não a deixe. E se alguma mulher tem marido descrente, e ele consente em habitar com ela, não o deixe. Porque o marido descrente é santificado pela mulher; e a mulher descrente é santificada pelo marido; de outra sorte os vossos filhos seriam imundos; mas agora são santos. Mas, se o descrente se apartar, aparte-se; porque neste caso o irmão, ou irmã, não esta sujeito à servidão; mas Deus chamou-nos para a paz. Porque, de onde sabes, ó mulher, se salvarás teu marido? ou, de onde sabes, ó marido, se salvarás tua mulher? [...] Ora, quanto às virgens, não tenho mandamento do Senhor; dou, porém, o meu parecer, como quem tem alcançado misericórdia do Senhor para ser fiel. Tenho, pois, por bom, por causa da instante necessidade, que é bom para o homem o estar assim. Estás ligado à mulher? não busques separar-te. Estás livre de mulher? não busques mulher. Mas, se te casares, não pecas; $e$, se a virgem se casar, não peca. Todavia os tais terão tribulaçōes na carne, e eu quereria poupar-vos. Isto, porém, vos digo, irmãos, que o tempo se abrevia; o que resta é que também os que têm mulheres sejam como se não as tivessem; [...] O solteiro cuida das coisas do SENHOR, em como há de agradar ao Senhor; Mas o que é casado cuida das coisas do mundo, em como há de agradar à mulher. Há diferença entre a mulher casada e a virgem. A solteira cuida das coisas do Senhor para ser santa, tanto no corpo como no espírito; porém, a casada cuida das coisas do mundo, em como há de agradar ao marido. [...] De sorte que, o que a dá em casamento faz bem; mas o que não a dá em casamento faz melhor. A mulher casada está ligada pela lei todo o tempo que o seu marido vive; mas, se falecer o seu marido fica livre para casar com quem quiser, contanto que seja no Senhor. Será, porém, mais bem-aventurada se ficar assim, segundo o meu parecer, e também eu cuido que tenho o Espirito de Deus. (1 Coríntios 7:1-40)

${ }^{12}$ De certa forma, Foucault (2006) recupera o projeto e as intuições de Marcel Mauss (2003) sobre a construção da noção de Eu individual/individualista própria ao ocidente. Diz Foucault (2006, p. 365): "Meu trabalho daqui em frente conduz ao problema da individualidade - ou, deveria eu dizer, da identidade em conexão com o problema do 'poder individualizante.." 
${ }^{13}$ Não temos espaço para explorar com mais profundidade as influências desses dois povos na formação do dispositivo do pastorado cristão. Para tal remetemos o leitor diretamente para Foucault (2006).

${ }^{14}$ Aqui é importante lembrar que a leitura de Bakhtin (1996) sobre o sexual, diferentemente da realizada por Foucault, tem uma influência mais marxista. Bakhtin discute as dimensōes sexuais da cultura das classes populares cristãs, contrapondo-a com uma cultura das elites da época.

${ }^{15}$ De graus de complexidade variáveis e que aqui foram apenas salientados alguns momentos escolhidos arbitrariamente.

${ }^{16}$ As hipóteses de Weber (2004) são importantes para a reflexão sobre o surgimento e avanço do Estado burguês na ordenação da vida social, em especial nos países do Norte do mundo. Não obstante, considerando a formação do Estado laico brasileiro, Montero (2006) explora, no seu percurso histórico, múltiplas formas de interlocução entre religião e Estado na vida social, mostrando que eles nunca conseguiram ficar inteiramente afastados. O fato é que na atualidade, quer em países do Norte ou do Sul, observa-se certo "retorno" da verdade religiosa à cena pública, processo qualificado por muitos autores como "perigoso". Representantes das religiōes, de forma crescente, vêm assumindo espaços de destaque dentro das instâncias do Estado (MARIZ, 2001; BERGER, 2001; MACHADO, 2003, entre outros), com impactos para a garantia de importantes princípios no campo dos Direitos Humanos, em especial o do respeito à diversidade. Para aprofundar o debate recente sobre isso no Brasil, cf. Duarte, Gomes et al (2009).

${ }^{17}$ Ressaltamos que muitos desses conceitos, ainda que não aprofundados, estão referenciados. Assim, a bibliografia apresentada pode servir como um roteiro para orientar outras iniciativas, que desdobrem e aprofundem os debates sobre a carne.

${ }^{18}$ Cf. especialmente: Rios, Paiva, Maksud et al. (2008); Rios, Aquino, Muñoz-Laboy et al. (2008) Seffener et al. (2008). 
On carnal inclinations: from early Christianity to the present

This study develops a historical review of the meanings of the "flesh" in the West, focusing on its significance in the context of Christianity. Our hope is that a study along these lines can help to illuminate current understandings of questions related to sexuality both within and outside of the religious contexts found in contemporary Brazil. Such questions are of special interest for those who are concerned with both old and new problems found in the field that has come to be known as sexual and reproductive rights, with implications for the field of Public Health.

> Key words: Christianity, sexuality, religion. 